\title{
Zimbabwe's Preparedness to Manage Meteorological Disasters as Informed By Disaster Risk Management
}

\author{
Farai Malvern Simba* \\ Great Zimbabwe University, Department of Physics, Geography and Environmental Science, Zimbabwe
}

Submission: October 08, 2018; Published: November 27, 2018

*Corresponding author: Farai Malvern, Great Zimbabwe University, Department of Physics, Geography and Environmental Science, Zimbabwe

\begin{abstract}
Climate change adaptation and building resilience among vulnerable communities can leverage on adoption of broader principles of Disaster Risk Management. In recent years many developing countries have seen an increasing push to merge Climate Change Adaptation (CCA) and Disaster Risk Reduction (DRR) approaches into a single framework because many of the tools developed by the disaster risk management (DRM) community, such as risk identification and preparedness are important to climate resilient development. The study sought to establish Zimbabwe's preparedness in managing meteorological disasters; mitigating climate change impacts using disaster risk management strategies; and to provide recommendations to help improve disaster preparedness in vulnerable communities in Masvingo province. Treating climate change as a natural disaster have far reaching positive results in dealing with climate change challenges in the country and beyond. One innovation adopted in this study is the use of an Android App to provide early warnings and other remedies after a disaster has struck. Given the wide use of Information technology products in Zimbabwe, minimum use of this App in managing climate change related disasters has shown it has potential to be effective especially for urban to peri-urban communities. The study established that the government is to a great extend prepared to manage disasters though more has to be done by availing more resources to avert impacts of disasters. Very little has been done to equip communities in terms of training and information dissemination especially in rural areas. The application developed was well received by communities and have great potential to inform vulnerable communities in preparation against disasters.
\end{abstract}

Keywords: Disaster; Climate change; Resilience; Adaptation; Communities; Zimbabwe

\section{Introduction}

The seriousness and urgency of climate change issues are now universally recognized. Climate change poses serious global challenges that will become worse in the future. Since the beginning of the 1990s, the United Nations has been promoting efforts to change the paradigm of disasters, advocating for the incorporation of disaster risk reduction efforts worldwide as a way to reduce the effects of natural hazards on vulnerable communities. In 2015, UNISDR facilitated the negotiations amongst Member States, experts and collaborating organizations; which led to the adoption of the Sendai Framework for Disaster Risk Reduction 2015-2030. Between 2015 and 2030, Member States around the world will conduct a variety of efforts within the context of the four Priority Areas contained in the Sendai Framework, as a way to reduce risks with the goal of minimizing losses due to the manifestation of hazards of natural origin. The government of Zimbabwe is party to the Sendai Framework for DRR 2015-2030.

Among developing countries especially, governments, civil society, the private sector and citizens face severe climate change impacts that require an array of policy responses [1]. These policy responses range from climate proofing of development programs, disaster risk management and preparedness, social protection and gendered extension programmes, water extraction and land use, and many others. The common focus of the CCA and DRR is reducing vulnerability and enhancing the resilience of societies to weather and climate hazards. In Zimbabwe the department of civil protection unit and Meteorological services department work, an acknowledgement of a need to merge CCA and DRR to better address challenges posed by meteorological and hydrometeorological hazards. Agriculture among other sectors is the most vulnerable to this global climate shift. This is because the land is becoming drier, with more variable and unpredictable rainfall distribution, frequency and intensity. Therefore, climate change is affecting agricultural activities severely and puts about $70 \%$ of the world poor and vulnerable group comprising of women on the frontline of coping with climate change impacts. It is affecting negatively the livelihoods and natural resources such as local crop biodiversity upon which people depend. Rural smallholder farmers' socio-economic conditions and food security are mostly affected as a result of this harsh agro-ecological change.

Acknowledging that "change in the Earth's climate and its adverse effects are a common concern of humankind," the United Nations Framework Convention on Climate Change (UNFCCC) 
calls for "the widest possible cooperation by all countries and their participation in an effective and appropriate international response, in accordance with their common but differentiated responsibilities and respective capabilities and their social and economic conditions." This call brought about the elements of Climate Change Adaptation (CCA) and Disaster Risk Reduction (DRR) which are widely recognised by UNFCCC in having a common focus on reducing the vulnerability of communities and contributing to sustainable development. The project sought to develop a user-friendly Android application dubbed Disaster proof App whose purpose is to provide pre and post disaster management strategies to communities both in urban and rural Masvingo province in events of natural disasters. Disaster risk management (DRM) is a topical issue in Zimbabwe and beyond both for the government and private sector as properties and lives have been lost [2].

Efforts in developing disaster management strategies are being made in an attempt to prepare and proof vulnerable communities especially in light of climate change that has brought extreme weather conditions [3]. Use of Information and Communication Technologies (ICTs) in this regard however is minimum in Zimbabwe despite a documented penetration of $103 \%$ of mobile phones and other ICT products [4].

\section{Problem statement}

Having experienced devastating floods, severe droughts resulting in food shortages and increased deaths of livestock, Zimbabwe's readiness to adapt or mitigate natural disasters has come under spotlight. The disasters and failure to cope by communities expose a huge knowledge-gap on how people within communities understand climate change disasters and the coping mechanisms and the study sought to establish the country's preparedness. In addition an innovation of employing ICTs on disaster management underpinned on merging climate change adaptation with disaster risk management strategies offers an opportunity for generating scientific evidence on the hybrid approach and its effectiveness.

\section{Objectives}

To manage climate change impacts using Disaster risk management strategies and ICTs.

To establish Zimbabwe's preparedness in managing meteorological disasters.

To provide recommendations to help improve disaster preparedness in vulnerable communities.

\section{Literature survey}

The UNFCCC defined CCA as the adjustments in natural or human systems in response to actual or expected climatic stimuli or their effects that moderate harm and exploit beneficial opportunities. These include:

a) Adapting development to gradual changes in average temperature, sea level and precipitation; and b) Reducing and managing the risks associated with more frequent, severe and unpredictable extreme weather events [5].

DRR is the concept and practice of reducing disaster risks through analysis and management of their causal factors. It reduces exposure to hazards, lessens the vulnerability of people and assets, and improves management of the land and environment, and preparedness for adverse events (UNISDR, 2009).

The general concepts of the CCA and DRR are:

a) Resilience: at which a resilient community is well-placed to manage hazards to minimize their effects and/or to recover quickly from any negative impacts.

b) Risk management approach: it is an excellent opportunity for the integration of the DRR and CCA in the communities so to provide a sound basis for making decisions on whether the risks are acceptable or intolerable.

c) No regrets actions: refers to the policies and actions that are beneficial to implement whether or not the consequences of climate change or disaster turn out as expected.

d) Mainstreaming: refers to the integration of policies and measures that address DRR and CCA into an ongoing sectoral planning and management.

According to United Nation International Strategy Disaster Reduction (UNISDR, 2009), the effects of climate change are magnifying the risk of disasters. They place additional burdens on humanitarian and development systems at all levels [6]. Climate change, including an increase in extreme weather and climate events, poses a threat to food security through erratic rainfall patterns and decreasing crop yields. The global climate change disasters and impacts which are now visible in all countries with developing countries most affected have spark the work of Great Zimbabwe University researchers to integrate CCA and DRR in Zimbabwe.

Definition of Terms According to Unisdr Terminology (2015)

\section{Disaster risk}

According to the terminology of UNISDR, disaster risk is defined as "the potential loss of life, injury, or destroyed or damaged assets which could occur to a system, society or a community in a specific period of time, determined probabilistically as a function of hazard, exposure, and capacity". In the technical sense, it is defined through the combination of three terms: hazard, exposure and vulnerability (Figure 1).

Disaster Risk Reduction «is aimed at preventing new and reducing existing disaster risk and managing residual risk, all of which contribute to strengthening resilience and therefore to the achievement of sustainable development». The UNISDR definition further annotates that "disaster risk reduction is the policy objective of disaster risk management, and its goals and 
objectives are defined in disaster risk reduction strategies and plans". Disaster Risk Reduction strategies and policies define goals

and objectives across different timescales, with concrete targets, indicators and time frames [7].

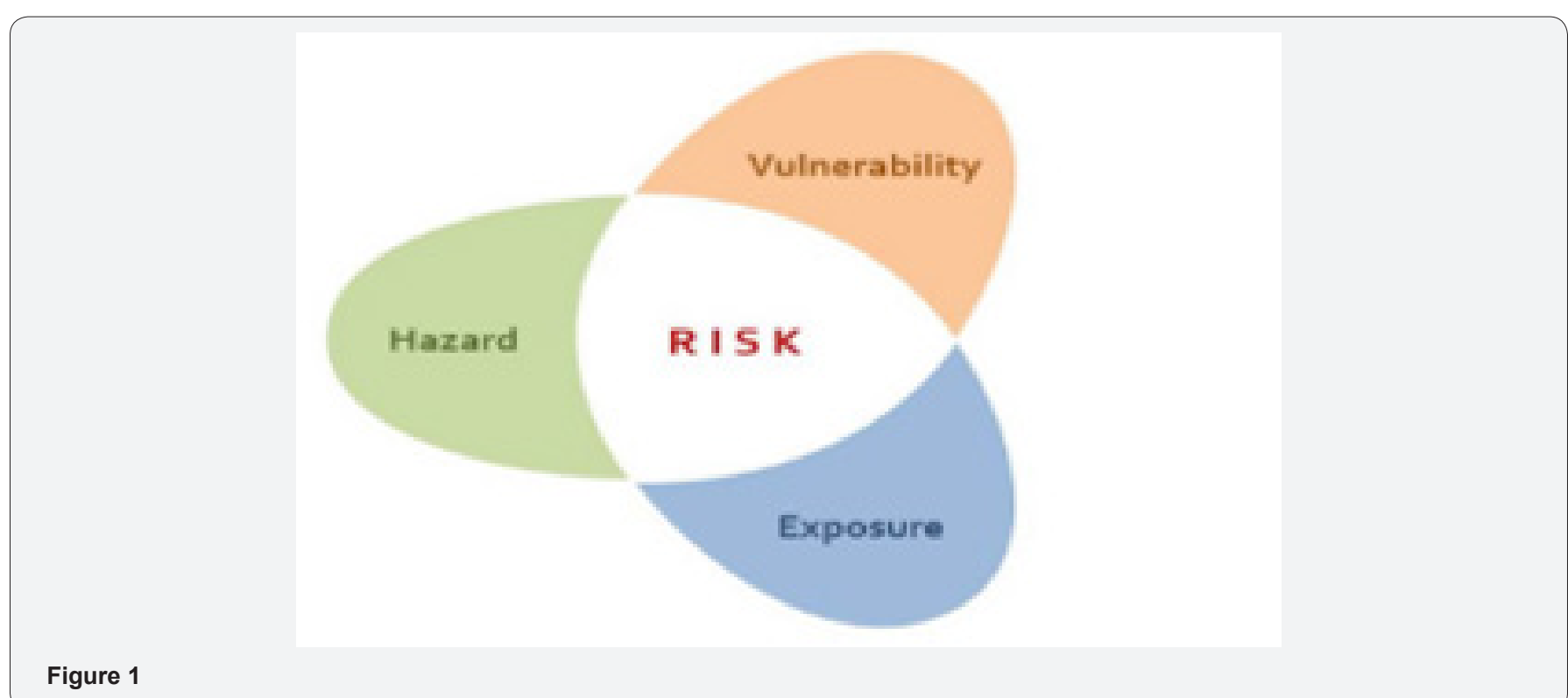

a) Disaster risk management is the application of disaster risk reduction policies and strategies, to prevent new disaster risks, reduce existing disaster risks, and manage residual risks, contributing to the strengthening of resilience and reduction of losses. Disaster risk management actions can be categorized into; prospective disaster risk management, corrective disaster risk management and compensatory disaster risk management (also referred to as residual risk management).

\section{Information management in disaster risk reduction}

In recent years, researchers and experts have been developing methods to conduct the assessment of hazards, vulnerability, and coping capacities; as well as techniques to combine such assessments in order to present them in risk map format. Such maps are essential in developing strategies to reduce the level of existing risks, and as a way to avoid a generation of new risks due to underlying social and economic risk drivers.

\section{Study area}

The study area was Masvingo urban and Masvingo south eastern region, rural areas. The region is located in the south-east low veld of the country where rainfall is minimal and uncertain. The southern parts of the region are drought prone and occur in agro-ecological region 5 of Zimbabwe's climatic regions. The area receives an average of $620 \mathrm{~mm}$ of rainfall per annum and average potential evapo-transpiration between $600-1000 \mathrm{~mm}$ which by far exceeds the avail- able water supply. The area has got an aridity index of between $0.2-0.5$ and means that the region is semi-arid. The average temperature of southeastern Zimbabwe is $19.4^{\circ} \mathrm{C}$. The range of average monthly temperatures is $9.5^{\circ} \mathrm{C}$. The warmest average maximum temperature is $34^{\circ} \mathrm{C}$ in October. The coolest average min temperature is $5{ }^{\circ} \mathrm{C}$ in July. Temperatures in parts of southeastern Zimbabwe, especially Chiredzi have risen by $0.6{ }^{\circ} \mathrm{C}$ since 1966 [8].

\section{Methodology}

The project was split over intervention and research work.

\section{Intervention}

Intervention involved development of the android app and giving it to community people both urban and rural. Desk work with computer experts developing the Android App by identifying key features and identify how they can be coded into Java program. The App program would then be developed and tested on a Java compiler. The App may not be exhaustive in addressing DRM issues but can be adopted to complement existing initiatives. The App was to do the following in English, Shona and Ndebele languages:

i. Provide hazard mapping and escape routes, Real Time and Automated information.

ii. Provide location based early warnings - can send alert tones.

iii. Provide a GPS link to provide location of the affected.

iv. Provide animated video clips illustrating: general Cardiopulmonary Resuscitation (CPR), measures after flooding, hailstorms, heat waves etc.

v. Provide toll free emergency numbers.

vi. Provide information upon prompting and also alert messages without prompts.

vii. Provide offline and online information for DRM.

viii. Provide short and long term location based mitigatory response/adaptation measures when different disasters strike. 
A comprehensive logical framework (log-frame) was developed to guide the intervention and for monitoring and evaluation. Information dissemination models were created for the rural and urban people in consideration of resource capacities as illustrated in $\mathrm{A}$ and $\mathrm{B}$ (Figure 2 \& 3) [9-12].

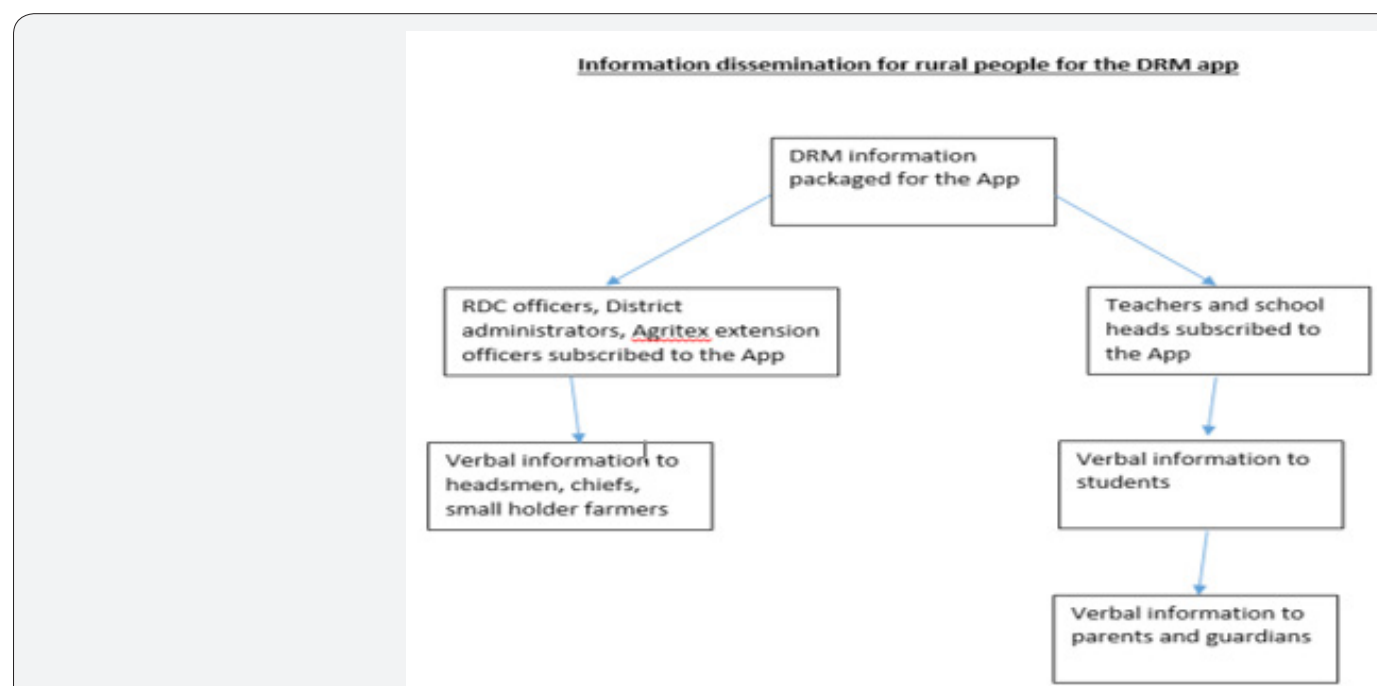

Figure 2: Rural information dissemination model.

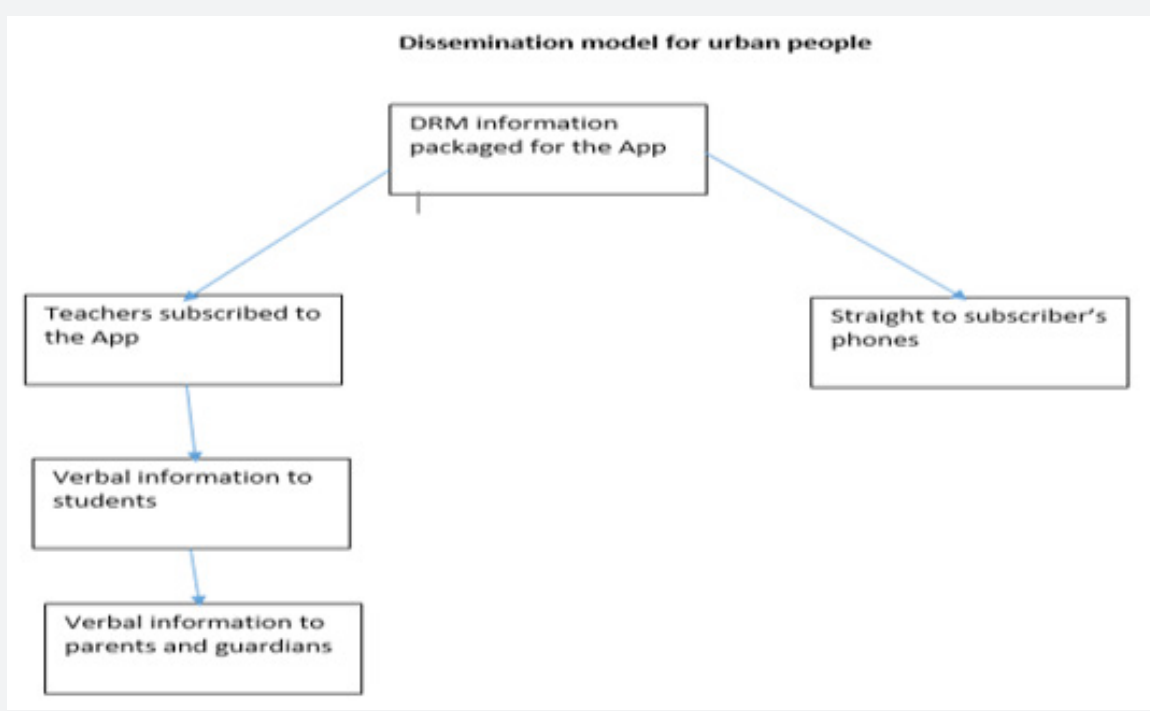

Figure 3: Urban information dissemination model.

Research work: Study area_the study areas were Masvingo urban-Rujeko high density surburb, Masvingo rural-Chivi, Ngundu and Chiredzi rural.

\section{Sampling of participants}

All participants were randomly selected. Masvingo urban -20 participants, with 13 women and 7 men, Masvingo ruralChivi had 10 respondents- 7 women and 3 men, Chiredzi rural 10-respondents- 4 men, 6 women.

\section{Data collection}

a) Both qualitative and quantitative data was collected.

b) Instruments used were fgd interview schedules, indepth interview schedules and questionnaires.

c) A baseline survey was conducted in Chivi, Ngundu and
Chiredzi rural areas as well as in town to establish the preparedness of communities in managing disasters, community perceptions and awareness.

I. Two field surveys meant for data collection from key informants and vulnerable communities and one project piloting excursion. Information on DRM strategies and government focus on DRM will be obtained from CPU and MSD through questionnaires and In-depth interviews.

II. Key informants consulted were CPU and MSD both in Harare.

\section{Theory of change}

The execution of the project was guided by a theory of change. The theory of change was as shown here: 
The theory of change explains how all the stakeholders and their efforts will be contributing to a community that is disaster proofed and resilient to disasters. The disaster management experts from Government relevant ministries, academics from universities, the development practioners and other interested technocrats designed a project based on an intervention and a research (Figure 4).

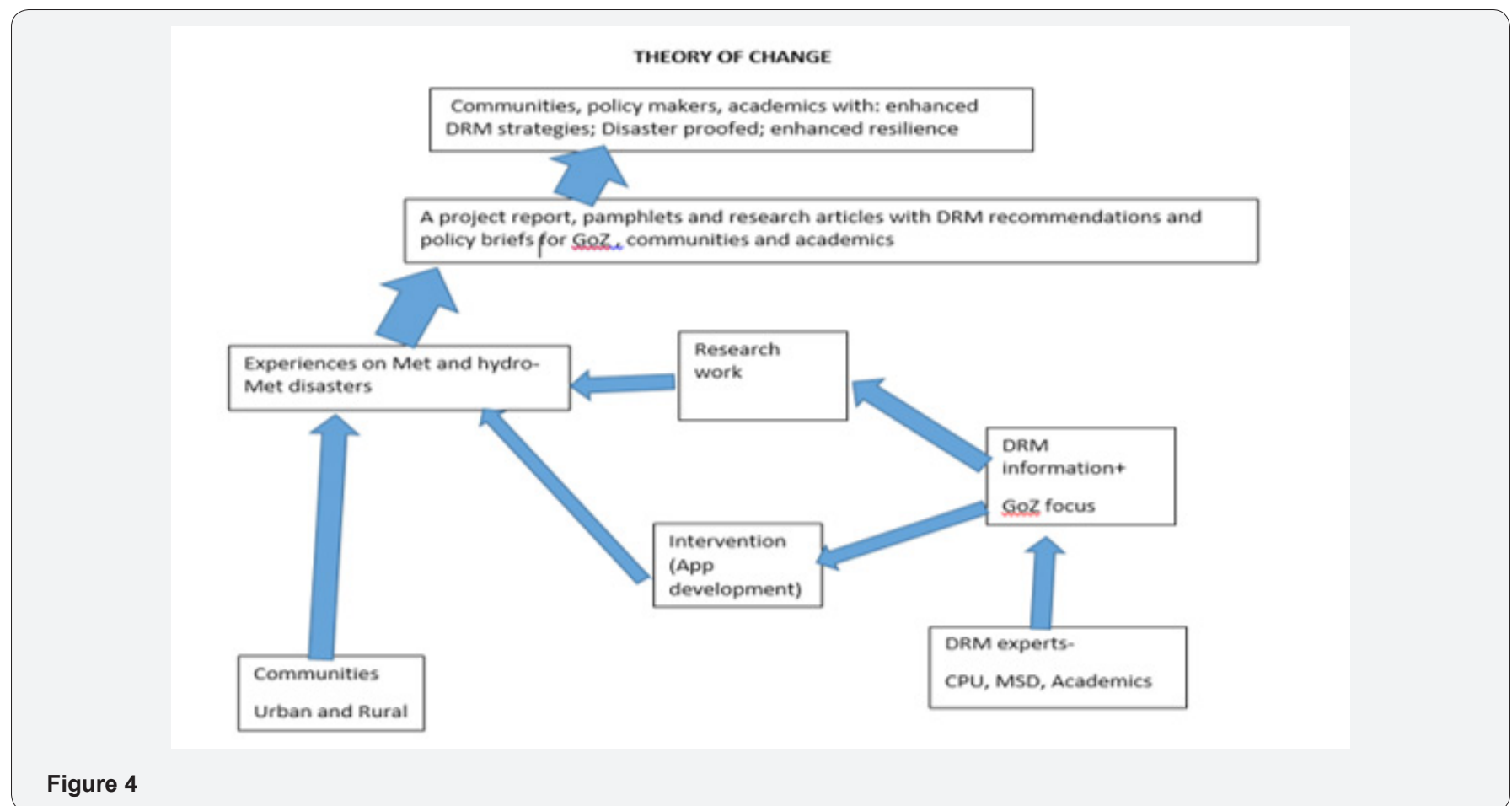

\section{Results and Discussion}

\section{Zimbabwe's preparedness from key informants}

\section{The government's focus in addressing issues of disaster risk} management in Zimbabwe

The Government through the department of Civil Protection has the primary role to saving lives, protection of property and the preservation of the environment. It is a national policy for Civil Protection that every citizen of this country should contribute where possible to avert or limit the effects of disaster. The Department of Civil Protection main rationale is to provide an overall coordination of all the stakeholders that are involved in Disaster Risk Management in Zimbabwe. Its mandate is derived from the Civil Protection Act Chapter 10.06 of 1989.The Act also outline that Civil Protection Department's main aim is to protect lives, property and the environment from all dangers.

a) The Government also adopted the Sendai Framework for Disaster Risk Reduction which have four priorities and the goal and the focus of the government is to prevent new and reduce existing disaster risk through the implementation of integrated and inclusive economic, structural, legal, social, health, cultural, educational, environmental, technological, political and institutional measures that prevent and reduce hazard exposure and vulnerability to disaster, increase preparedness for response and recovery, and thus strengthen resilience aims in the country

b) The department also have the Civil Protection Fund which is assisting families and individuals who are involved in a disaster

What the civil protection unit department has done to empower communities and build resilience in as far as DRM are concerned

a) The department of $\mathrm{CP}$ through the Civil Protection Act Chapter 10:06 of 1989 formed the Civil Protection Committee which has a structural background from village level, ward level district level, provincial level and national level. At any level the DCP responses to disaster as to provide humanitarian assistance. Moreover, at the national level there is National Civil Protection Committee which include stakeholders, partners, institution of higher learning, government department and private sectors

b) Partner with institution of higher learning to research on scientific measures to reduce disasters disaster management was introduced at BUSE and NUST

c) Updated manuals for schools so that DRM can also introduced in the Ministry of Primary and Secondary Education

d) Introduced Community Disaster Risk Reduction programmes both in rural and urban areas

e) Disaster Risk Reduction and awareness campaigns for the people living with disability was introduce in 2017 to involve everyone in disaster management

f) Education and awareness campaigns was done through the STCZ, ZRP to reduce road traffic accidents, with the Min of 
Health and Child Care during Cholera outbreak and EMA on environmental protection

Government budgetary commitments from treasury sufficient to address DRM issues

The funds from treasury is in sufficient to address DRM issues hence UNDP assisted the department with vehicles which used at district, provincial and national level to respond to disasters

Efforts on the integration of DRM issues in addressing challenges of climate change-how the relevant government ministries work together

Statistics have shown that meteorological hazards are the major disasters that lead to the destruction of property, environment and an increase on death around the country. The department then integrates DRM issues very well to address the challenges of climate change

a. The department together with MSD working on a national framework for climate change services.

b. Update the catalogue together of the hydrometeorological hazards such as floods, drought, strong winds, cyclones, frost and heat waves.

c. Mapping the flood hazard map.

Department of climate change management

a) Taking National Adaptation Plan (NAP) projects in both urban and rural areas on Climate Change as to create a climate change resilient economy. b) Implementing the SECA Project in LUPANE, Bulilima and Gokwe South District after adopting the 2015 Paris Agreement on Climate Change.

\section{Water management department}

Implementing Integrated Water Resources Management in the Save Catchment

Extend of application of ICTS by the civil protection department in disaster management

The department only adopted the use of cell phones to send alert messages to the nation and adverts on radio stations.

The department also use WhatsApp to send messages to the nation on prevailing hazards However the use of GIS, GPS and Remote Sensing as well as the use of ICT was not yet adopted within the field of DRM the department however, used GIS to map flood prone areas in Zimbabwe for flood assessment

\section{Zimbabwe's preparedness to tackle disasters and extend}

To a lesser extend the country can tackle disasters however due to resources constraints the country cannot tackle disasters effectively.

How the development practitioners (Ngos) worked to complement government programmers on DRM

UNDP- sponsored funds and vehicles to the department to able to tackle disasters

Save the Children- Funded the programs the Department take on educational and awareness campaigns on disasters

\section{Some of the challenges faced in addressing disasters in Zimbabwe and what are possible solutions (Table 1)}

Table 1

\begin{tabular}{|c|c|}
\hline Challenges & Solutions \\
\hline Lack of financial support & Seek support from development partners \\
\hline $\begin{array}{c}\text { Shortage of resources to respond to meteorological } \\
\text { hazards }\end{array}$ & Seek resources from developmental partners \\
\hline $\begin{array}{c}\text { Shortage of experts in using ICTs and GIS and Remote } \\
\text { Sensing in tracing hydro-meteorological hazards such as } \\
\text { floods, drought and cyclones }\end{array}$ & $\begin{array}{c}\text { Funding higher and tertiary institution to engage in scientific } \\
\text { research in the use of ICT in DRM and DRR }\end{array}$ \\
\hline $\begin{array}{c}\text { Political Constraints to deal with the occurrence of haz- } \\
\text { ards in Zimbabwe }\end{array}$ & $\begin{array}{c}\text { Give precedence and a chance for everyone to engage in Disaster } \\
\text { Risk Reduction even NGO's }\end{array}$ \\
\hline $\begin{array}{c}\text { Inaccessible of some areas since they are remote areas to } \\
\text { address disasters in Zimbabwe }\end{array}$ & $\begin{array}{c}\text { Use of GIS, GPS and Remote sensing as well as ICT's in addressing } \\
\text { disasters in Zimbabwe }\end{array}$ \\
\hline
\end{tabular}

Issues of gender and youth empowerment integrated in government's programming in disaster management (Table 2)

Table 2

\begin{tabular}{|c|c|}
\hline Government Programs & How \\
\hline Youths-empowered to know more about DRM and DRM & Through education and awareness campaigns workshops \\
\hline $\begin{array}{l}\text { Women-to know more about the disasters of Climate change } \\
\text { especially drought }\end{array}$ & Community Based Disaster Risk Management \\
\hline $\begin{array}{l}\text { School children-empowered to know about dangers of hydro } \\
\text { meteorological hazards }\end{array}$ & $\begin{array}{l}\text { Through production of DRM materials for schools to educate } \\
\text { them on dangers of hazards }\end{array}$ \\
\hline
\end{tabular}


How the vulnerable groups of society integrated in DRM programming by the government?

a) Through community-based disaster risk reduction.

b) Education and awareness campaigns.

Some of the government policies that address DRM issues

a) The 2015 Paris Agreement on Climate Change.

b) The 17 Goals of Sustainable Development.

c) Civil protection Bill of 2013 .

State of early warning equipment at meteorological services department (MSD) and if it can it be relied on to give accurate data

Most of the equipment for weather forecasting at MSD are fully functional and softwares updated regularly through World Meteorological Organization (WMO) run programs. However, one of the most important tool for early warming, Dopler Radars, broke down more than a decade ago and have not been repaired since. The reason being that they are very costly to either repair or buy new ones. This year (2018) though, the government released funds for the purchase of several Radars to be placed in different parts of the country.

\section{The country's position to monitor development and progres-} sion of an approaching windstorms

The main tool the MSD has for storm monitoring is Satellite receivers. However, non-availability of radars is a problem. On wind storms, the ones which normally affect Zimbabwe are accompanied by thunderstorms or cyclones, which are well monitored in the department through climate models and satellite imagery amongst other tools.

\section{Perceptions from the Community}

a. All respondents acknowledged that there were aware of the existence of meteorological disasters and had experienced it at one point or another.

b. Years of meteorological disasters that came out topical were 1992 (drought), 2008 (drought), 2016/2017 season (floods)

c. All acknowledged that they had lost some property due to the disasters directly and indirectly.

d. Droughts, floods, army worm, cholera were cited as the most common disasters in the area.

e. Only 5 out of 40 said there were prepared for disasters the rest were not and required assistance from the government.

f. 5 out of 40 were trained the rest not trained through the district structures for disasters management at the District administrator's office

g. None was trained on CPR or first aid to help disaster victims. h. How do you get your information on disasters, information like early warnings and impact mitigation strategies?

i. All acknowledged that they get information through radio, $\mathrm{TV}$, messages from the chief, extension officers and district administrators.

j. The Android Application was received well by the youth mostly who have smart phones and are more comfortable with technological products. They appreciated mostly the different languages in which it can be used, the animations on CPR tips, the early warnings and the information on evacuation routes.

k. The model for information dissemination proposed especially for the rural folk has a potential to work if there is more sensitization and awareness work to accompany it.

I. People use phones to get information especially through social media and internet-urban, rural people do not use much ICTs.

Generally, communities take heed when CPU and MSD issue out warnings and take necessary measures recommended.

a. Rural people rely on Indigenous Knowledge Systems as well for early warnings especially during the rainy season. Some Urban people do, the rest do not.

b. Generally, people relate to occurrences of disasters to spirituality.

\section{Conclusion and Recommendations}

Generally, people both in urban and rural setups are aware of the existence of meteorological disasters but are not equipped to withstand their impacts. People are not trained on CPR or help others who will be drowning in floods. Efforts are being made however by the CPU to disseminate information on managing disasters through radio, TV and sms messages. There is a lot of work going on at CPU and MSD in managing disasters in the country though more provision of funding, more research, more interventions (capacity building) still need to be done. MSD need to have their radars working to provide more accurate early warnings. CPU needs more resourcing to improve their sensitization, awareness campaigns and capacity building of communities in light of disasters. All stakeholders have to come on board to help build resilience of communities against disasters.

The merging of DRM and climate change impacts management has far reaching benefits and proved to be a comprehensive and informed approach. It works very well in building resilience and proofing communities against meteorological disasters. In addition there is a positive effort in terms of policy by the government, on disaster management in the country. Use of ICTs have to be improved and embraced more at government and community level as it is still minimum. The talk of an App was received quite well among the youths and less in middle aged to old people. 


\section{References}

1. Simba FM, Chayangira J (2017) Rainfall seasons analysis as a guiding tool to small-holder farmers in the face of climate change in Midlands in Zimbabwe. J Earth Sci Clim Change 8:392

2. UNISDR (2009) Global Assessment report on Disaster risk reduction. International strategy for Disaster Reduction Geneva.

3. Cardona OD (2009) Disaster risk and vulnerability: Notions and measurement of human and environmental insecurity. Coping with global environmental change disasters and security Threats, challenges, vulnerabilities and risks. Hexagon series on human and environmental security and peace. Vol 5.

4. ACCCKF (2014) UNICEF Zimbabwe report on climate change looking at women, children and the disabled.

5. UNSD (2010) Environmental Indicators (unstats.un.org/unsd/ environment/Hydro_disasters.htm)

6. Marulanda MC, Cardona OD, AH Barbat (2008) The economic and social effects of small disasters: Revision of the local disaster index and case study of Colombia, Megacities Resilience and Social Vulnerability. United Nations University. Munich Bonn.

7. Birkmann J (2006) Measuring vulnerability to hazards of natural origin. Towards disaster resilient societies. United Nations University, Tokyo, New York, USA, pp. 480.

8. Chikodzi D, Murwendo T, Simba F (2013) Climate change and variability in South East Zimbabwe Scenarios and societal opportunities American Journal of Climate Change (2): 36-46.

9. Indicators for Disaster Risk and Risk Management (2011) Technical Note, Program for the Caribbean, Belize.

10. Sendai Framework for disaster risk reduction (2015-2030) $20153^{\text {rd }}$ UN World conference in Sendai Japan.

11. The UNISDR Terminology (2015) preventionweb.net.

12. UNISDR (2015) Understanding Disaster Risk. preventionweb.net.

Your next submission with Juniper Publishers will reach you the below assets

- Quality Editorial service

- Swift Peer Review

- Reprints availability

- E-prints Service

- Manuscript Podcast for convenient understanding

- Global attainment for your research

- Manuscript accessibility in different formats

( Pdf, E-pub, Full Text, Audio)

- Unceasing customer service

Track the below URL for one-step submission https://juniperpublishers.com/online-submission.php 